\title{
PROBLEMATIKA PROSES PEMBELAJARAN BAHASA INDONESIA SECARA DARING PADA MASA COVID 19
}

\author{
Bambang Irawan \\ e-mail: bambangirawan030589@gmail.com \\ Prodi Tadris Bahasa Indonesia \\ IAI Darussalam Blokagung Banyuwangi
}

\begin{abstract}
Abstrak
Sebagaimana dewasa ini, dunia telah dihadapkan pada suatu permasalahan yang terjadi yaitu mewabahnya virus corona atau yang dikenal dengan Corona virus Disease 2019 (Covid-19). Pemerintah Indonesia melalui Mentri pendidikan dan budaya (Mendikbud), Nadiem Anwar Makariem, telah mengeluarkan surat edaran no 4 tahun 2020 tentang Pelaksanaan Pendidikan Dalam Masa Darurat Coronavirus Disease (Covid-19). Surat edaran tersebut memuat beberapa hal teknis terkait proses pembelajaran yang harus dilaksanakan oleh civitas akademika. Salah satu kebijakan tersebut adalah menekankan kepada civitas akademika untuk melaksanakan pembelajaran secara dalam jaringan (daring) dengan tujuan untuk mencegah penyebaran virus covid-19. Penelitian ini bertujuan untuk mengetahui apa sajakah problematika proses pembelajaran bahasa Indonesia secara daring pada masa covid 19 di SMA Darussalam dan bagaimanakah solusinya dari problrmatika tersebut. Pendekatan peneletian ini menggunakan pendekatan penelitian kualitatif dengan teknik pengumpulan data dengan cara wawancara kepada informan yang berkaitan dengan penelitian ini. Teknik analisis data yang digunakan menggunakan teknik analisis domain dan taksonomi. Hasil penelitian menunjukkan bahwa problematika proses pembelajran bahasa Indonesia secara daring adalah kurangnya sarana prasana seperti halnya siswa tidak membawa handphone, keterbatasan waktu,kesulitan mengevaluasi, rawan terdapat kecurangan dalam mengerjakan tugas, susah sinyal, dan kurang pahamnya wali murid. Solusi dari problematika tersebut adalah perlunya dukungan dari stakeholder untuk ikut andil dalam kesuksesan proses belajar secara daring. Stakeholder tersebut meliputi guru, orang tua, murid, sekolah dan pemerintah.
\end{abstract}

Kata Kunci: Problematika, Proses Pembelajaran Bahasa Indonesia, Daring

\begin{abstract}
As it is today, the world has been confronted with a problem that occurs that is the epidemic of the corona virus, known as Coronavirus Disease 2019 (Covid-19). The Indonesian Government through the Minister of Education and Culture (Mendikbud), Nadiem Anwar Makariem, has issued a circular number 4 of 2020 concerning the Implementation of Education in the Coronavirus Disease Emergency Period (Covid-19). The circular contains several technical issues related to the learning process that must be carried out by the academic community. One such policy is to emphasize the academic community to carry out learning online (online) with the aim of preventing the spread of the covid-19 virus. This study aims to find out what are the problems of the online learning process in Indonesian during the 19th period in MA Darussalam and how is the solution of the problem. This research approach uses a qualitative research approach with data collection techniques by interviewing informants related to this research. Data analysis techniques used are domain and taxonomy analysis techniques. The results showed that the problematic of the process of learning Indonesian online is the lack of infrastructure such as students not carrying a cellphone, time constraints, difficulty evaluating, prone to cheating in doing assignments, difficult signal, and lack of understanding of student guardians. The solution to the problem is the need for stakeholder support to contribute to the success of the online learning process. These stakeholders include teachers, parents, students, schools and government.
\end{abstract}

Keywords: Problems, Indonesian Language Learning Process, Online 


\section{A. Pendahuluan}

Sebagai seorang Muslim, belajar merupakan sebuah kewajiban. Sebagaimana Rasulullah bersabda bahwa "mencari ilmu (belajar) wajib hukumnya bagi seorang Muslim. Hal ini mengindikasikan bahwa mencari ilmu sangatlah penting karena dengan ilmu manusia bisa menciptakan kreasi yang unik dan spektakuler dalam berkehidupan bermasyarakat. Mencari ilmu dapat dilakukan dalam berbagai cara, kondisi, waktu dan lain sebagainya. Namun bagaimana jika mencari ilmu dalam keadaan dimana terdapat wabah/virus yang berbahaya yang dapat mengancam banyak nyawa?

Dalam Islam mencari ilmu adalah perintah agama, utamanya ilmu tentang hal-hal pokok yang terkait dengan kewajiban asasi dalam agama seperti shalat dan puasa maupun kebutuhan hidup sehari-hari, seperti sandang, pangan dan papan untuk diri dan keluarga. Sebab orang yang mencari ilmu sudah pasti tidak terhindar dari tempat dan terjadi di dalam waktu/masa. Madrasah, sekolah, kampus, dan pondok pesantren adalah salah satu pilihan tempat mencari ilmu. Tempat-tempat itu tentu dikelola oleh pihak penyelenggara yang sudah semestinya ada penjenjangan belajar, masa belajar, libur belajar, dan seterusnya. Ilmu dipelajari bukan sekadar agar mengerti, melainkan harus bertujuan memenuhi kebutuhan kehidupan sebagaimana halnya kebutuhan rezeki/pangan untuk bertahan hidup. Seseorang yang tidak makan atau minum dalam waktu tertentu dapat mengalami kelaparan bahkan mati. Demikian pula ketika jiwa/hati yang tidak dikasih makan, yaitu ilmu pengetahuan khususnya ilmu agama, tentu hatinya akan gersang bahkan lama-lama juga mati.Sepanjang masih hidup, mereka tidak boleh terlepas dari ilmu dan makanan untuk keberlangsungan hidup jiwa dan raganya. Oleh sebab itu, belajar dalam masa wabah/virus bukan alasan untuk berhenti belajar sebagaimana halnya tidak alasan berhenti makan.

Sebagaimana dewasa ini, dunia telah dihadapkan pada suatu permasalahan yang terjadi yaitu mewabahnya virus corona atau yang dikenal dengan Coronavirus Disease 2019 (Covid-19). Coronavirus atau virus coronamerupakan keluarga besar virus yang menyebabkan infeksi saluran pernapasan atas ringan hingga sedang, seperti penyakit flu. Banyak orang terinfeksi virus ini, setidaknya satu kali dalam hidupnya. Namun, beberapa jenis virus corona juga bisa menimbulkan penyakit yang lebih serius, seperti: Middle East Respiratory Syndrome (MERS-CoV), Severe Acute Respiratory, Syndrome (SARS-CoV), Pneumonia. 
SARS yang muncul pada November 2002 di Tiongkok, menyebar ke beberapa negara lain. Mulai dari Hongkong, Vietnam, Singapura, Indonesia, Malaysia, Inggris, Italia, Swedia, Swiss, Rusia, hingga Amerika Serikat. Epidemi SARS yang berakhir hingga pertengahan 2003 itu menjangkiti 8.098 orang di berbagai negara. Setidaknya 774 orang mesti kehilangan nyawa akibat penyakit infeksi saluran pernapasan berat tersebut. Sampai saat ini terdapat tujuh coronavirus (HCoVs) yang telah diidentifikasi, yaitu: HCoV-229E, HCoV-OC43, HCoV-NL63, HCoV-HKU1, SARS-COV (yang menyebabkan sindrom pernapasan akut), MERS-COV (sindrom pernapasan Timur Tengah), COVID-19 atau dikenal juga dengan Novel Coronavirus (menyebabkan wabah pneumonia di kota Wuhan, Tiongkok pada Desember 2019, dan menyebar ke negara lainnya mulai Januari 2020. Indonesia sendiri mengumumkan adanya kasus covid 19 dari Maret 2020. (Fadli, 2019)

Setelah Indonesia mengumumkan adanya kasus covid 19, Pemerintah Indonesia melalui Mentri pendidikan dan budaya (Mendikbud), Nadiem Anwar Makariem, telah mengeluarkan surat edaran no 4 tahun 2020 tentang Pelaksanaan Pendidikan Dalam Masa Darurat Coronavirus Disease (Covid-19). Surat edaran tersebut memuat beberapa hal teknis terkait proses pembelajaran yang harus dilaksanakan oleh civitas akademika. Salah satu kebijakan tersebut adalah menekankan kepada civitas akademika untuk melaksanakan pembelajaran secara dalam jaringan (daring) dengan tujuan untuk mencegah penyebaran virus covid-19.

Pembelajaran secara dalam jaringan adalah pembelajaran dengan memanfaatkan teknologi dengan jangkauan luas dan dapat memiliki kriteria seperti: (1) daring merupakan jaringan yang mampu menyimpan, memperbaharui, mendistribusikan dan membagi bahan ajar atau materi, (2) pengiriman sampai ke pengguna terakhir melalui komputer dengan menggunakan teknologi internet yang standar, (3) memfokuskan pada pandangan yang paling luas tentang pembelajaran di balik paradigma pembelajaran tradisional (Rosenberg 2001; 28). Pembelajaran secara daring merupakan perkembangan ilmu pengetahuan dan teknologi atau IPTEK yang saat ini dapat membantu untuk memberikan informasi pembelajaran yang semakin luas dan interaktif khususnya dalam pembelajaran bahasa Indonesia (Asih, 2016:232).

Menurut Arsyad $(2002,15)$ bahwa dalam proses pembelajaran ada dua unsur yang sangat penting yaitu metode dan media pembelajaran. Pemilihan salah satu metode 
mengajar dapat mempengaruhi jenis media pengajaran yang sesuai sehingga harus benar dan tepat media yang dipilih agar tujuan proses pembelajaran dapat diterima secara efektif.

Menurut Rosid (2019:199) Pelaksanaan pembelajaran khususnya untuk Kurikulum 2013 merupakan implementasi RPP yang harus mengacu pada Permendikbud Nomor 65 Tahun 2013 tentang Standar Proses Pendidikan Dasar dan menengah. Pencapaian tersebut dapat dilakukan dengan beberapa faktor slah satunya adalah menggunakan komputer (internet). Internet sebagai media pembelajaran sangatlah mungkin menjadi partner guru dan siswa dalam kegiatan belajar mengajar jika guru dan murid dapat mengoperasionalkan media tersebut namun komputer (internet) hanyalah alat bantu atau media yang sepenuhnya tergantung penggunanya jika tidak bisa mengoperasionalkannya maka juga akan menimbulkan problematika bagi civitas akademika (Asih, 2016:233).

\section{B. Metode Penelitian}

Pendekatan yang digunakan dalam penelitian ini adalah melalui pendekatan kualitatif. Pendekatan kualitatif adalah pendekatan dengan menggunakan data yang berupa kalimat tertulis atau lisan, peristiwa-peristiwa, pengetahuan, atau proyek studi yang bersifat deskriptif (Nazir, 2003:54). Metode penelitian kualitatif digunakan untuk meneliti kondisi yang alamiah dimana peneliti adalah sebagai instrument kunci, teknik pengumpulan data dilakukan secara triangulasi (gabungan), analisis data bersifat induktif atau kualitatif, dan hasil penelitian kualitatif lebih menekankan makna daripada generalisasi (Sugiyono, 2012:9).

Penelitian ini bertujuan untuk menjawab rumusan masalah yaitu bagaimana problematika civitas akademika dalam melaksanakan proses pembelajaran bahasa indonesia secara dalam jaringan (Daring) di era corona (studi pada kelas X ,MIPA 1 SMA Darussalam Blokagung Banyuwangi). Jenis penelitian kualitatif ini menggunakan metode studi kasus. Penggunaan studi kasus merupakan strategi yang cocok digunakan untuk menjawab pertanyaan "bagaimana" yang mana dalam peneliti hanya memiliki sedikit peluang untuk melakukan kontrol terhadap objek penelitian yang akan diselidiki (Yin, 2012:1).

Alasan penggunaan strategi studi kasus adalah; pertama, studi kasus memungkinkan hasil penelitian suatu peristiwa-peristiwa kontemporer sulit untuk dimanipulasi (Yin, 
2012:12). Peristiwa yang dimaksud dalam penelitian ini adalah bagaimana problematika civitas akademika dalam melaksanakan proses pembelajaran bahasa indonesia secara dalam jaringan (Daring) di era corona. Tehnik pengumplan data dalam penelitian menggunakan metode wawancara kepada informan yang terkait dengan penelitian ini dan dokumentasi. Tehnik analisis data dalam penelitian ini menggunakan tehnik analisis domain dan taksonomi.

\section{Hasil Dan Pembahasan}

\section{a. Problematika Pembelajaran Bahasa Indonesia Secara Daring}

Proses pembelajaran bahasa Indonesia hakikatnya untuk meningkatkan kemampuan berfikir dan bernalar serta kemampuan memperluas wawasan (Asih, 2016: 71). Proses pembelajaran bahasa Indonesia yang dilakukan oleh SMA Darussalam telah mengalami perubahan metode setelah adanya covid. Sebelum adanya covid 19, pembelajaran bahasa Indonesia menggunakan metode yang berpusat pada guru dengan tatap muka langsung. Namun setelah adanya covid 19 metode yang digunakan adalah metode yang berpusat pada siswa (discovery/inquiry). Hal ini dilakukan karena pada saat masa covid 19, proses pembelajaran bahasa Indonesia di SMA Darussalam dilakukan secara daring untuk pencegahan penularan virus covid 19 yang penularannya dapat dilakukan melalui kerumunan atau tatap muka. Walaupun begitu 2 metode dalam pembelajaran tersebut diperbolehkan menurut Sapani (1997:55).

Berdasarkan hasil penelitian menunjukkan bahwa terdapat problematika dalam pembelajaran bahasa Indonesia secara daring di SMA Darussalam Blokagung Banyuwangi. Problematika tersebut meliputi:

1. Kesulitan penerapan proses pembelajaran secara daring di sisa semester 1 karena mayoritas siswa adalah santri pondok pesantren yang bermukim di pesantren dengan tanpa membawa handphone sehingga dampaknya adalah materi semester 1 banyak yang tertinggal. Hasil penelitian ini selaras dengan penelitian Aji (2020) dengan judul penelitian "Dampak Covid 19 pada pendidikan di Indonesia: sekolah, ketrampilan dan proses pembelajaran" dengan hasil penelitian yang menunjukkan bahwa masalah pembelajaran daring yang muncul adalah keterbatasan penguasaan teknologi informasi baik siswa maupun guru sehingga menghambat proses pembelajaran.

2. Guru bahasa Indonesia yang ada di SMA Darussalam relatif sedikit yang terlibat dalam proses pembelajaran daring hal ini juga selaras dengan penelitian Aji (2020) 
bahwa masalah yang dihadapi saat pembelajaran daring adalah sarana prasarana pendukung yang kurang memadai.

3. Waktu yang digunakan dalam proses pembelajaran secara daring dirasa masih belum cukup untuk menyampaikan materi dan belum maksimal.

4. Sulitnya lembaga untuk mengevaluasi proses pembelajaran secara daring karena guru tidak datang ke kantor untuk melaksanakan administrasi setelah proses pembelajaran sebagaimana yang telah dilakukan sebelum terjadinya covid 19.

5. Siswa mengerjakan tugas secara curang dengan cara mengerjakan bersama-sama dengan siswa lain yang padahal dalam perintah guru harus mengerjakan sendirisendiri. Sehingga permasalahan yang muncul adalah hasil tugas siswa sulit untuk menjadi acuan penilaian untuk evaluasi proses pembelajaran. Hasil ini tidak selaras dengan penelitian yang dilakukan oleh Santoso (2009) dengan judul penelitian "Pengaruh Pembelajaran Online Terhadap Prestasi Belajar Kimia Ditinjau dari Kemampuan Awal Siswa : Studi pada Siswa SMA Negeri 1 Purwantoro, Wonogiri” yang menunjukkan hasil penelitian bahwa justru dengan pembelajaran melalui daring dapat meningkatkan prestasi belajar. Hasil penelitian Santoso (2009) selaras dengan hasil penelitian Khusniyah (2019) dengan judul "efektifitas pembelajaran berbasis daring: sebuah bukti pada pembelajaran bahasa Inggris" dengan hasil penelitian menunjukkan bahwa pembelajaran daring memberikan pengaruh yang positif terhadap peningkatan membaca bahasa Inggris mahasiswa.

Selain 5 poin tersebut terdapat problematika lain yang muncul sebagaimana hasil wawancara sebagai berikut:

"Kendala ...hemmm kendalane (kendalanya) kadang sinyal sulit, terus kuata habis, enek seng gak duwe hp (ada yang gak punya hp) kui kanggo siswa (itu buat siswa), tapi lek gurune ( tapi kalau gurunya) kurangnya absen, pemberitauan pada wali murid.kadang onok wali murid seng gak ngerti anak e pas waktu pembelajaran daring (kadang ada wali murid yang gak tau anaknya pas waktu pembelajaran daring, waktu terbatas, tidak maksimal ,biaya lebih mahal."

Berdasarkan hasil wawancara di atas menunjukkan bahwa ada beberapa problematika lain yaitu sebagai berikut:

6. Terkendala dengan sulitnya sinyal 
7. Kehabisan kuota karena dalam proses pembelajaran daring diperlukan kuota data yang banyak.

8. Terdapat siswa yang tidak memiliki handphone sehingga kesulitan untuk mengikuti proses pembelajaran secara daring.

9. Sulitnya mengevaluasi guru terkait presensi kehadiran (absen)

10. Tidak pahamnya wali murid terkait proses pembelajaran secara daring.

Problematika di atas selaras dengan hasil penelitian Aji (2020) yaitu hasil penelitiannya menunjukkan bahwa masalah yang menghambat terlaksananya efektivitas pembelajaran dengan metode daring diantaranya adalah: 1. Keterbatasan Penguasaan Teknologi Informasi oleh Guru dan Siswa Kondisi guru di Indonesia tidak seluruhnya paham penggunaan teknologi, ini bisa dilihat dari guru-guru yang lahir tahun sebelum 1980-an. Kendala teknologi informasi membatasi mereka dalam menggunakan media daring. Begitu juga dengan siswa yang kondisinya hampir sama dengan guru-guru yang dimaksud dengan pemahaman penggunaan teknologi. 2. Sarana dan Prasarana yang Kurang Memadai Perangkat pendukung teknologi jelas mahal. Banyak di daerah Indonesia yang guru pun masih dalam kondisi ekonominya yang menghawatirkan. Kesejahteraan guru maupun murid yang membatasi mereka dari serba terbatas dalam menikmati sarana dan prasarana teknologi informasi yang sangat diperlukan dengan musibah Covid-19 ini. 3. Akses Internet yang terbatas Jaringan internet yang benar-benar masih belum merata di pelosok negeri. Tidak semua lembaga pendidikan baik Sekolah dasar maupun sekolah menengah dapat menikmati internet. Jika ada pun jaringan internet kondisinya masih belum mampu mengkover media daring. 4. Kurang siapnya penyediaan Anggaran Biaya juga sesuatu yang menghambat karena, aspek kesejahteraan guru dan murid masih jauh dari harapan. Ketika mereka menggunakan kuota internet untuk memenuhi kebutuhan media daring, maka jelas mereka tidak sanggup membayarnya. Ada dilema dalam pemanfaatan media daring, ketika menteri pendidikan memberikan semangat produktivitas harus melaju, namun disisi lain kecakapan dan kemampuan finansial guru dan siswa belum melaju ke arah yang sama. Negara pun belum hadir secara menyeluruh dalam memfasilitasi kebutuhan biaya yang dimaksud.

\section{b. Solusi Problematika Pembelajaran Bahasa Indonesia secara Daring}


Hasil penelitian menunjukkan bahwa solusi dalam problematika pembelajaran bahasa Indonesia secara daring jika berkaitan dengan sarana prasarana maka solusinya adalah sekolah dapat menggunakan dana bantuan operasional sekolah (BOS) dari pemerintah untuk subsidi kepada guru dan siswa untuk pembelian kuota atau internet yang dapat digunakan untuk pembelajaran secara daring. Namun jika problematika pembelajaran daring berkaitan dengan evaluasi pembelajaran maka peran guru dan orang tua sangat dibutuhkan. Hasil penelitian ini terkait solusi pembelajaran daring selaras dengan penelitian Aji (2020) tentang langkah strategis bagi dunia pendidikan Indonesia yaitu:

\section{Pemerintah}

Peran pemerintah sangat penting dan fundamental. Alokasi anggaran yang sudah diputuskan oleh Instruksi Presiden Nomor 4 tahun 2020 tentang refocussing kegiatan, relokasi anggaran, serta pengadaan barang dan jasa dalam rangka percepatan penanganan Covid-19 harus segera dilaksanakan.

2. Orang Tua

Orang tua sebagai pendidik utama di rumah tangga harus menjalankan fungsinya. Meskipun demikian tetap saja bantuan guru di sekolah perlu hadir door to door disemua peserta didik. Ini harus membuka cakrawala dan tanggungjwab orang tua bahwa pendidikan anaknya harus dikembalikan pada effort orang tua dalam mendidikan mental, sikap dan pengetahuan anakanaknya.

3. Guru

Langkah pembelajaran daring harus seefektif mungkin. Guru bukan membebani murid dalam tugas-tugas yang dihantarkan dalam belajar di rumah. Jika perlu guru hadir secara gagasan dalam door to door peserta didik. Guru bukan hanya memposisikan sebagai pentransfer ilmu, tetapi tetap saja mengutamakan ing ngarso sung tulada, ing madya mangun karsa, tut wuri handayani.

4. Sekolah

Sekolah sebagai lembaga penyelenggara pendidikan harus bersiaga memfasilitasi perubahan apapun menyangkut pendidikan siswanya. Pendidikan tingkah laku harus menjadi pijakan kuat ditengah perkembangan teknologi dan arus percepatan informasi. Program-program pendidikan yang dilakukan sekolah harus benar-benar disampaikan kepada murid, terlebih dengan media daring tetap saja pihak sekolah harus benar-benar memperhatikan etika sebagai lembaga pendidikan. Penekanan 
belajar dirumah kepada murid harus benar-benar mendapat kawalan agar guru-guru yang mengajar melalui media garing tetap smooth dan cerdas dalam menyampaikan pelajaran-pelajaran yang wajib dipahami oleh murid.

\section{Kesimpulan}

1. Problematika dalam proses pembelajaran bahasa Indonesia secara daring adalah sebagai berikut:

a. Kesulitan penerapan proses pembelajaran secara daring di sisa semester 1 karena mayoritas siswa adalah santri pondok pesantren yang bermukim di pesantren dengan tanpa membawa handphone sehingga dampaknya adalah materi semester 1 banyak yang tertinggal.

b. Guru bahasa Indonesia yang ada di SMA Darussalam relatif sedikit yang terlibat dalam proses pembelajaran daring.

c. Waktu yang digunakan dalam proses pembelajaran secara daring dirasa masih belum cukup untuk menyampaikan materi dan belum maksimal.

d. Sulitnya lembaga untuk mengevaluasi proses pembelajaran secara daring karena guru tidak datang ke kantor untuk melaksanakan administrasi setelah proses pembelajaran sebagaimana yang telah dilakukan sebelum terjadinya covid 19.

e. Siswa mengerjakan tugas secara curang dengan cara mengerjakan bersama-sama dengan siswa lain yang padahal dalam perintah guru harus mengerjakan sendirisendiri. Sehingga permasalahan yang muncul adalah hasil tugas siswa sulit untuk menjadi acuan penilaian untuk evaluasi proses pembelajaran.

f.Terkendala dengan sulitnya sinyal

g. Kehabisan kuota karena dalam proses pembelajaran daring diperlukan kuota data yang banyak.

h. Terdapat siswa yang tidak memiliki handphone sehingga kesulitan untuk mengikuti proses pembelajaran secara daring.

i. Sulitnya mengevaluasi guru terkait presensi kehadiran (absen)

j. Tidak pahamnya wali murid terkait proses pembelajaran secara daring.

2. Solusi problematika pembelajaran daring adalah perlunya dukungan dari stakeholder untuk ikut andil dalam kesuksesan proses belajar secara daring. Stakeholder tersebut meliputi guru, orang tua, murid, sekolah dan pemerintah.

\section{Daftar Rujukan}


Aji, Rizqon. 2020. Dampak Covid 19 pada pendidikan di Indonesia: sekolah, ketrampilan dan proses pembelajaran. Jurnal SALAM UIN Syarif Hidayatullah Jakarta (Online), Vol 7 No. 5. (file:///C:/Users/Rtb/Downloads/15314-45974-1-PB.pdf diakses pada tanggal 25 Juli 2020 pukuk $01.44 \mathrm{WIB}$ )

Alwi, Hasan. 2001. Kamus Besar Bahasa Indonesia. Jakarta: Balai Pustaka.

Arikunto, Suharsimi. 2006. Prosedur Penelitian : Suatu Pendekatan Praktik, Edisi Revisi VI, Jakarta : PT Rineka Cipta.

Airtanah, A. (2014). Bab ii kajian teori. Bab Ii Kajian Teori, (1), 9-34.

Arsyad, Azhar. 2007. Media Pembelajaran. Jakarta: Raja Grafindo Persada.

Asih. 2016. Strategi Pembelajran Bahasa Indonesia. Bandung: CV Pustaka Setia.

Khusniyah, N.L \& Hakim.L. 2019. Efektifitas Pembelajaran Berbasis Daring: Sebuah Bukti pada pPembelajaran Bahasa Inggris. Jurnal Tatsqif, (Online), Vol 17 no 1. (file:///C:/Users/Rtb/Downloads/667-Article\%20Text-1636-2-10-20190720.pdf diakses pada tanggal 25 Juli 2020 pukul 00.40 WIB).

Muryati, Sri dan Kusumaningsih, Dewi. 2011. Strategi Pembeljaran Bahasa Indonesia, Sukoharjo: Univet Bantara.

Rosid, M. H. Al. (2019). Pengaruh Pelaksanaan Kurikulum K-13 Terhadap Peningkatan Mutu Pendidikan SMK Darussalam Blokagung. Jurnal Manajemen Pendidikan Islam (JMPID), 1(1), 194-214. https://ejournal.iaida.ac.id/index.php/jmpid/article/view/529

Santoso, Edi. 2009. Pengaruh Pembelajaran Online Terhadap Prestasi Belajar Kimia Ditinjau dari Kemampuan Awal Siswa : Studi pada Siswa SMA Negeri 1 Purwantoro, Wonogiri. Tesis tidak diterbitkan. Program Studi Teknologi Pendidikan Program Pascasarjana Universitas Sebelas Maret Surakarta

Sapani, Suardi. 1997. Teori Pembelajaran Bahasa. Jakarta: Depdikbud.

Suyatno. 2007. Pembelajaran Koperatif Inovatif. Surabaya: Media Buana Pustaka. 